\title{
Barriers to Elementary School Teachers' Professional Practice: Teachers' Voice
}

Putu Nanci Riastini, Yogyakarta State University, Ganesha University of Education, Indonesia, putunanci.2017@student.uny.ac.id, putunanci.riastini@undiksha.ac.id, ORCID:0000-0002-6727-0959

Ni Wayan Surya Mahayanti, Yogyakarta State University, Ganesha University of Education, Indonesia, ni0018pasca.2019@student.uny.ac.id, surya.mahayanti@undiksha.ac.id, ORCID: 0000-0002-0181-8993

IGP Suryadarma, Yogyakarta State University, Indonesia, suryadarma@uny.ac.id, ORCID: 0000-0001-60152303

Muhammad Nur Wangid, Yogyakarta State University, Indonesia, m_nurwangid@uny.ac.id, ORCID: 00000003-0348-9238

\begin{abstract}
Professional practice is a crucial factor for teachers to be able to do their profession well. Its development has to be sustainable to achieve educational quality. However, the process cannot run optimally caused by various barriers faced by the teachers in the field. The objective of this study was to explore the phenomenon of the barriers to public elementary school teachers, in developing their professional practice. In order to achieve these goals, this study used qualitative descriptive design. Data collection used the triangulation methods. The data analysis was thematic analysis. There are seven barriers found to the teachers' professional practice. The barriers are too much work, teachers' commitments and support from their colleagues, principal's leadership, effectiveness of involvement in professional development activities, effectiveness of teachers' work groups as a forum for teachers' professional development, discrepancies between curriculum requirements and demands in the field, and weak teacher-parent partnership.
\end{abstract}

Keywords: Barriers, Elementary School, Teachers, Professional Practice

Received: $15.11 .2020 \quad$ Accepted: 04.12.2020 Published: 02.01.2021

\section{INTRODUCTION}

Education is a critical factor in developing human resources, especially education in primary schools. Elementary education aims at laying the essential foundation for the students' development (Griffin et al., 2012; Kolbe, 2015; Riastini, Wati, et al., 2019; Saavedra \& Opfer, 2012; Smith \& Hu, 2013). This foundation has a significant contribution to sustainable human resources development in the $21^{\text {st }}$ century. The foundation can be constructed through the role of elementary school teachers who play the role as the spearhead for the human resources development at that level (Riastini, Widowati, et al., 2019; Sumaryanta et al., 2018). In other words, elementary school teachers are a vital aspect of the educational development.

Elementary school teachers have the primary duty of preparing the children for facing various problems in their lives. As the four pillars of education by UNESCO, that learning includes learning to know, learning to do, learning to be, and learning to live together (Delors et al., 1996). In order to shoulder such heavy responsibility as this requires from the teachers the capability of playing the role of learner facilitator (Ghorbani et al., 2018). Traditional teaching in the form of activities looking for answers to a number of questions and pieces of information (Otero \& Llanos, 2019) are no longer appropriate to use. The learning that they manage should be active, and innovative which can train the students to solve real problems in their lives (Griffin et al., 2012; Thomson \& Gregory, 2013; Yüksel, 2014). Besides, they also have to be involved in the use of technology in education as the means to train the students to master it (Ilomäki et al., 2014; Kunter et al., 2013; Martín-gutiérrez et al., 2015; Schleicher, 2012; Yüksel, 2014). Another factor that is not less in importance is their self-motivation to do their duties, which is a crucial factor in their competence and quality of professional practice development (Altınay-Gazi, 2017; Bicer \& Capraro, 2017; Dixon et al., 2014; Fishman et al., 2013; Skaalvik \& Skaalvik, 2011; Vermunt \& Endedijk, 2011). In short, elementary school teachers' professional practice plays a vital role in producing the quality of education at that level.

However, of course, there are various problems related to teacher's professional practice that are mostly faced in elementary schools. For example, six elementary school teachers in Taiwan who were involved in a study had inadequate pedagogical knowledge, pedagogical, pedagogical content knowledge, and technological pedagogical knowledge (Liu, 2013). A study of 207 elementary school teachers in Geneva 
showed that the most common teaching strategy used by the teachers was the traditional teaching strategy (Buchs et al., 2017). The traditional teaching took the form of a classroom discussion that involved all the students monitored by the teacher and the students and individual student work. Another finding was that the competence of 3000 elementary school teachers in Washington State was low in evaluating assessment to make decisions, in understanding presented validity and reliability, in explaining scoring scales to the parents (Gotch \& French, 2013). The teachers were also uninterested in professional development workshops on evaluation. Another study was done with 201 elementary school teachers in Turkey, which showed that the self-efficacy in the technology of the teachers with few years of experience (6-10 years and 11-15 years) had a higher level than those with many years of experience (Tuba et al., 2013). A result of a study with 252 elementary schools in Kirikkale, Turkey, showed that competence in the use of technology or the internet, navigation, email, social media, office application is at the highest and the medium positions (Celik, 2012). However, the teacher's competence in the aspect of designing their teaching with the interactive whiteboard and implementing the teaching using the material was at the lowest level. The illustrations above show that elementary school teacher professional practice is a complex problem in many countries.

The complexity of elementary school teachers' professional practice problems is also found in Indonesia. For example, a study on pedagogic competence with 107 teachers in Tomohon, North Sulawesi, showed that the longer a teacher has taught, the lower his or her competence will be (Zedko \& Sumual, 2017). Teaching at elementary school has not touched deeply and contextually an aspect of life, in this case, waste problem (Riastini, Wati, et al., 2019). Consequently, there was no integration between the knowledge and skills that the students have acquired. A study with 213 elementary school teachers in Bali showed that there is a cultural discontinuity in teaching, and many teachers cannot use technology to support teaching (Riastini, Widowati, et al., 2019). It affects meaningful learning and students' outcome. This shows that there are many problems with the elementary school teachers' professional practice.

Various programs have been carried out by various parties, especially by the ministry of education, to overcome the problem (for example, teacher working group forums $(K K G)$ as a forum for teachers to develop their professional). Another example is the program Better Education through Reformed Management and Universal Teacher Upgrading (BERMUTU) in 2014, intending to improve the quality of education (Winingsih, 2013). However, the results of the teacher competency test conducted in 2015 showed a surprising fact. The national average of elementary schools' teacher competency was only at 40.14 (KEMDIKBUD, 2020). Based on these results, other programs have been developed to continuously improve teacher competencies, such as Learners' Teacher Competency Enhancement Program (LTCEP) (Sumaryanta et al., 2018). After the implementation of the program, unfortunately, the increase in the national average teacher competency test only reached a figure below 70 in 2016 and 2017 (Ministry of Education and Culture, 2020). This phenomenon indicates that there are factors that inhibit the development of elementary school teacher professional practice in Bali, Indonesia. However, unfortunately, there have been no studies done that have shown the barriers to the elementary school teachers' professional practice development comprehensively. Hence, this study was oriented to exploring more intensively the issue based on information from the teachers. The information obtained can be a basis for consideration to develop education and training programs for elementary school teachers in the context of professional development.

\section{METHODS}

\section{Research Design}

The objective of this study was to explore the phenomenon of the barriers to public elementary school teachers in Bali, Indonesia, in developing their professional practice. In order to achieve these goals, this study used qualitative descriptive design. The design was aim to study phenomenon and its character in real situation (Nassaji, 2015). Which means that the study was not aim to discover new theory from the data collected.

\section{Data Collection}

Data collection involved three techniques, namely surveys using open question questionnaires, documentation, and focus group discussions (FGD), as seen on Figure 1. 


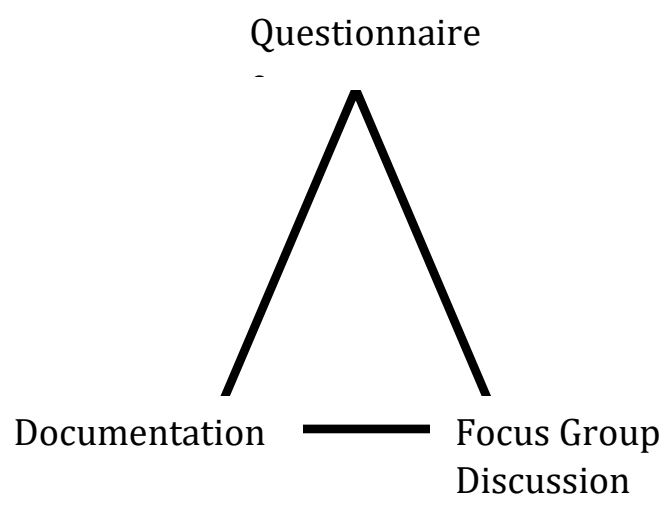

Figure 1. Triangulation Methods

Data collection using surveys involved 75 public elementary school teachers from across nine districts in Bali. They have a service life of below 20 years. They were asked to complete the questionnaire sent to them. They did not give their identities on the questionnaire. The types of surveys were written surveys and electronic surveys. These two types were done because there was a different internet connection between one place and another. The questionnaire used an open-ended question format. There were ten questions asked. The questions covered 1) teacher's workload, 2) self-commitment to school culture, 3) professional development and forum for professional development, 4) curriculum and its implementation, and 5) cooperation between parents and teachers. At the end of the questionnaire, the teachers were asked to attach documents related to the topic. Furthermore, the FGD aims to facilitate participants to be able to interact with each other on the topic, so that data obtained that support the results of the survey. Ten teachers were involved in a 1-hour FGD, and their responses were recorded for data analysis.

\section{Data Analysis}

The data analysis which were involved in this study was thematic analysis. This technique is able to explain the importance of respondents' experience (Morse \& Field, 1995). The data analysis was started by transcribing verbal data collected. The transcriptions were then identified multiple times to find out units of meaning contained in them. Furthermore, the units of meaning collected were summarized and again identified multiple times to find out the similarities and differentiation. The units of meaning, which were similar, were then categorized into themes (Ada \& Kartal, 2020). Lastly, those themes were reported.

\section{RESULTS and DISCUSSION}

The results of the study showed the barriers to the public elementary school teacher professional practice in Bali, Indonesia. The results were presented in some themes, namely too much work, teachers' commitment and support from their colleagues, principal's leadership, involvement in professional development activities, effectiveness of teachers' workgroups as a forum for elementary school teachers' professional development, discrepancy between curriculum requirements and demands in the field, and weak working relationship between the teachers and the parents.

\section{Too much Workload}

The teachers' too much workload was the most significant barrier to their professional practice and its development. In addition to the requirement to teach for 24 hours a week, the teachers are required to do too much teaching administration (for example, a lesson plan that consists of many pages with a rigid format and assessment reports) that use up their energies. They also have other additional tasks that they have to pay their attention to. The teachers are asked to do administrative work unrelated to teaching, such as in managing school operational, financial aid (well known as BOS), worker's job performance target, administrating salaries and incentives, uploading self-administrative data through different applications in each given period, become operators of primary educational data, and other tasks. 


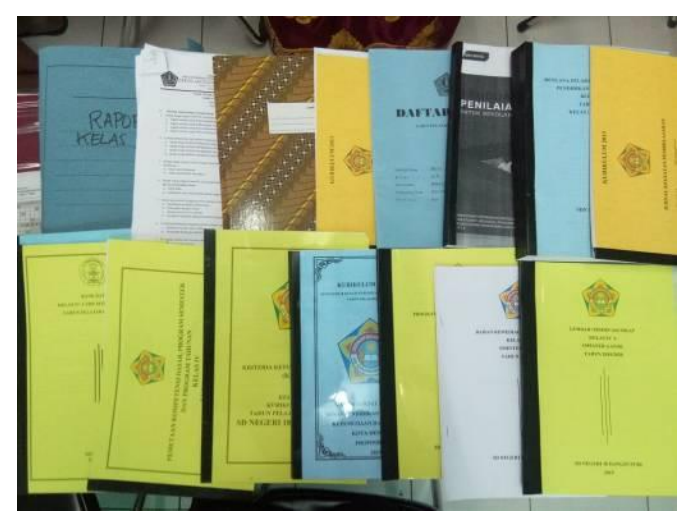

Figure 2. Teaching Administration

In other words, the workload given to the teachers consists of teaching and clerical work. As a consequence, the teachers feel that they do not have enough time to do their primary duty well, to develop their self-competence, to do things for themselves and their families. One of the statements quoted is as follows.

"Most of my work is outside teaching; teaching administration is, of course, a task that a teacher has to do. However, because of a new curriculum, the teacher is also busier doing the new curriculum contents and completing its administration than teaching. Besides, the additional tasks are given to the teacher often makes the teacher leave the classroom in which no teacher replaces him or her. For example, the teacher becomes a financial officer of the school operational, financial aid, or a clerk who is responsible for the main educational data. Sometimes he or she forgets whether he or she is a teacher of a clerk."

The factors that cause problems in teacher professional practice include too many administrative requirements (Tanang et al., 2014). Similar problems are also faced by the teachers in Singapore who have overloaded teaching and administrative tasks (Hairon \& Dimmock, 2012). Too much workload harms the teacher, especially in his or her motivation and job satisfaction (Skaalvik \& Skaalvik, 2011). Too much workload also affects the implementation of the curriculum and teacher professional development (Burgess et al., 2010).

\section{Teachers' Commitments and Support from their Colleagues}

The teachers' awareness to work wholeheartedly is one form of their professional commitment. Unfortunately, the teachers' low commitment is collective and becomes a barrier to their professional practice. Some of such teachers work as government workers and the others as non-government (private) workers. Most of them have professional certificates. This phenomenon is also common among old teachers with long years of experience. They are less enthusiastic about doing their jobs, less creative in managing the teaching, and have problems in the use of computers and other teaching equipment. However, they are accustomed to using gadgets for searching and using various social media. They use gadgets not only outside the classroom but also in the classroom. Nevertheless, they are not used for teaching. In other words, the low commitment among the teachers affects their professional practice and the development. Commitment and competence are related to each other (Shukla, 2014). The low level of teacher dedication caused teachers to become bored, and this harms their job satisfaction (Høigaard et al., 2012). Therefore, teacher professional development is significant to make teachers effective and schools successful (Gemeda \& Tynjälä, 2015).

Then, the work climate at school causes teachers to adjust to the existing system. For example, support from colleagues is essential for developing teacher professional practice. Many teachers experience an increase in performance due to the optimal support from their colleagues. The teachers who have a dedication to their jobs stop their dedication because of less support from their colleagues. In short, cultural context plays an essential role in teacher professional practice (Hairon \& Dimmock, 2012). Teachers who work at a school with a favorable climate experience fewer problems in their rooms (Brennan et al., 2014). In other words, social support from their partners helps teachers to exchange opinions about their professional problems, have more achievement, and produce job satisfaction (Bogler \& Somech, 2004; I'Anson \& Eady, 2017; Kinman et al., 2011).

One of the statements made by the teacher related to teacher dedication and his colleague support is as follows.

"Most of my colleagues are contract teachers and government workers who are going to retire. Their commitment to quality is shallow. Their teaching routines include entering and going out of the classroom 
and going home. All look mechanical, moreover, if it is supported by the headmaster who is also going to retire. Their thinking and program are still far from positive. The school operational, financial aid is used not for things that are urgent (directed to teaching). Just to spend the school money."

"My friends have various levels of dedication as teachers. Some do not have enough dedication, those who are diligent, and continue learning. Some are lazy. Some still motivate others not to follow the teachers who give a bad example."

\section{Principal's leadership}

Principals play an essential role in developing teacher professional practice. Support from the principal to the process of teacher performance improvement is crucial for teacher performance. So is the monitoring process and supervision from the principal. However, unfortunately, the monitoring and supervision both from the principal and the school supervisor are less optimal in some schools. Lack of appreciation and the difficulty in obtaining permission from the principal for teachers to participate in professional development activities become one of the forms of the absence of support from the principal to teacher professional practice development. Similarly, monitoring and supervision. Although these processes are done, they tend to be done formally to meet the accreditation and the internal quality assurance standard. Such a problem causes a delay in teacher professional practice development. An example of the statements given by a teacher related to this is as follows.

"A lack of appreciation for performances from the principal so that there is no motivation to do innovation."

"The supervision is also done if needed, for example, for accreditation or the meet the internal quality assurance standard."

Principals play a vital role in sustainable education in schools (Gemeda \& Tynjälä, 2015). Effective leadership is one of the components that play a critical role in teacher professional development, which has a positive effect on the school development, and student learning achievement (Huber \& Muijs, 2010; KILINÇ, 2014). Principal's support to teachers has the potentiality for the development of teachers' motivation and satisfaction (Allen et al., 2015; Eyal \& Roth, 2011; Tajasom \& Ahmad, 2011). Principal's evaluation also plays a significant role in teacher professional development (Delvaux et al., 2013).

\section{Involvement in Professional Development Activities}

Self-professional development for teachers is significant in sustainably enhancing their performances. Teachers stated that they have ever had a professional development training with various objectives, such as to have experiences, collect credit points, and just follow the trend among their friends. However, the opportunity and the habit of doing it still limited. The lack of time available causes it because of an overload of work. If teachers have the opportunity to have the training, participation is often less optimal and lack of focus. It is caused by the lack of teachers' participation as active participants in the training activities, the mismatch between the training content and the teachers' needs in the classroom, the lack of participation from the relevant parties to do a follow-up activity, and the demands of other tasks that have to be completed at the same time.

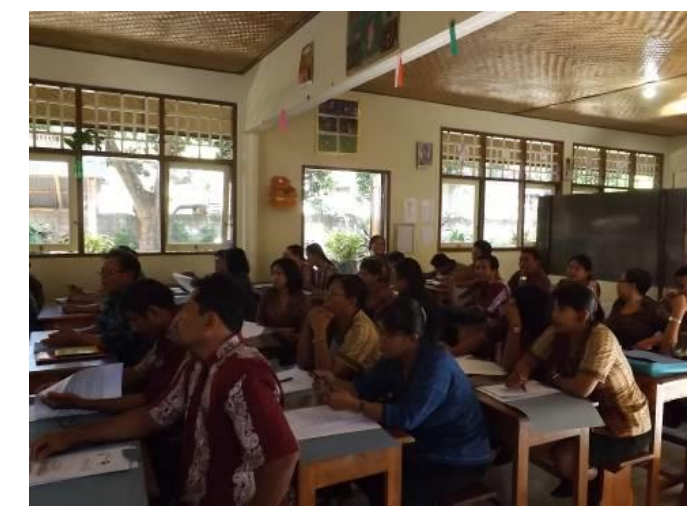

Figure 3. Teachers' Participation in the Training Activities

The factors that cause problems in teachers' lack of competence include commitment, attitude, and lack of teachers' habits to develop themselves (Tanang et al., 2014). The lack of training for selfdevelopment becomes a constraint to the development of professional teachers (Anyolo et al., 2018). In the context of professional development, training that teachers need are those that are suitable for their classrooms' needs and involve the teachers in the activities (An \& Reigeluth, 2011; Bayar, 2014). Events of 
exchange experience allow teachers to learn new things and practice it (Berestova et al., 2020). Besides, the stakeholders need to be involved in the effort to develop teacher professional development (Whitworth \& Chiu, 2015). Hence, teacher collaborative activities, in-service training, and classroom observation have a very significant effect on an optimal improvement of school quality (Hoque et al., 2011).

"Seldom has the opportunity to have the training and to apply its results."

\section{Effectiveness of Teachers' Work Group as a Forum for Elementary School Teachers' Professional Development}

Teacher Work Group (known as KKG) is a forum for teacher professional development at the elementary school level in Indonesia. However, it is often the case that there is a low contribution to the activities of professional development through KKG to the improvement in teacher professional practice. KKG activities are generally done at the beginning of the school year and the end of the semester only. The activities done at those times focus more on the writing of lesson plans and assessment instruments. The activities that are related to the problems such as local culture integration into the teaching, learning resources development that involves the use of various technologies, innovative teaching practices, and other trendy problems faced at school have not been touched. It is caused by the KKG activities that have not been programmed and managed well. Communication and collaboration among KKG member teachers have not been developed, and the limitation of human resources to lead the activities. As a result, KKG serves only as a formality, and the process is not sustainable. The examples of the teachers' statements are as follows.

"Since so far, KKG is often done at the beginning of the school year or before the semester evaluation."

"KKG is only held to write lesson plans and an end of semester assessment."

The professional learning community is an essential forum for teachers to develop self-competence. It has the potentiality to give sustainable support (An \& Reigeluth, 2011). The community needed is the one that is collaborative and has interdependence among its members so that they can share each other, give feedback, and develop commitments to a teacher better development (Lee et al., 2011; Parker et al., 2012; Zakharov et al., 2020). The contents also have to be meaningful, according to the teachers' needs, and learning conditions that give the opportunity to actively try new things (Vangrieken et al., 2017). The competent professional and professional facilitator's role in guiding teachers is also very supportive of a teachers' community (Kim et al., 2012; Parker et al., 2012). Unclear program management which is less relevant to the teachers' needs, the still low innovation, insufficient infrastructure and facilities, less creative tutors, teachers who are not actively involved, time limitation, and policies that are not supporting cause KKG activities to lack a positive effect on teacher professional practice and the sustainability of the community (Parker et al., 2012; Rahayu, 2011).

\section{The discrepancy between Curriculum Requirements and Demands in the Field}

The curriculum that is being used in Indonesia this time is the 2013 Curriculum. This curriculum requires that the teaching process be integrated, so that the knowledge, attitude, and religious domains, and skill are comprehensively dealt with. The evaluation is no longer in the form of scores. It is in the form of descriptions about the attainments in the domains. The teaching media and learning resources also vary to help the students reach the learning objectives. The class size has also been regulated in the curriculum to ensure a maximum teaching process. However, the implementation of the curriculum in the field has caused discrepancies in teacher professional practice.

The discrepancy that happened between the class size exceeds the size determined in the curriculum, and this is common in many public schools. One class has 40 students, or more even the number can be 50 . With that size, the teacher has problems in adjusting the planning and the teaching based on student characteristics. Similarly, the teacher faces problems in handling classes with various problems. The teacher needs more time to facilitate the students to acquire competence; on the other hand, the time available in one semester is limited. Academic and behavior guidance is not maximal either. The enrichment and remedial teaching are only written in the administration document. The teacher cannot find additional hours because of the administrative tasks that he or she has to do, and the teacher cannot find the time to do the enrichment and remedial teaching. Teacher professional practice and quality of teaching are also neglected. Such a class causes the teacher to lose quality time to do the teaching, the communication between the teacher and the students is weak, and the teacher cannot identify learning difficulties well (Fan, 2012). Big class size affects the accuracy of the teacher's diagnosis; the attention given to the students is also limited, and the ineffective classroom process is of course related in a complex way to the teacher professional (Blatchford et al., 2011; Brühwiler \& Blatchford, 2011). Changes or adaptations in various teaching approaches are also a challenge and are difficult to be made in a big class (Mulryan-kyne, 2010). 
The following example shows that sufficient teaching media and learning resources do not support curriculum implementation. The number of learning resources that are available in many schools does not meet the school need the media used are also limited to downloaded pictures, audios, or videos. The media that use higher technology are not available. The availability of technological devices to support the teaching process is very limited. This case happens in towns, and the condition in villages is even worse. Teachers also have problems with time and the mindset that they have about the previous curriculum. This phenomenon also becomes a barrier for teachers to develop their professional. The new curriculum, of course, needs 1) revision in various parts, such as teaching process, learning resources, and digital environment; 2) adequate time to fully implement changes; 3) changes in the teacher's perspective of the new curriculum, and 4) cost (Burgess et al., 2010; Cooper, 2017; Keesing-styles et al., 2013). On the other hand, the limited skill on the part of the teachers in IT and the number of teaching media based on IT that is not yet adequate influence teacher competence (An \& Reigeluth, 2011; Tanang et al., 2014). For this reason, the teacher's development to face changes that occur is needed very badly to make teachers have the relevant competence (Cooper, 2017; Keesing-styles et al., 2013).

Another phenomenon is that the evaluation requirements in the field are very complex and are separated for each subject. Thus the teachers are confused, especially to harmonize the teaching process and the evaluation process. The teaching process is an integrated process, but the evaluation is separated for each subject. The condition is worsened by an unwritten "regulation" that students have to be promoted to a higher grade or to pass with the minimum completeness criterion (which is called KKM). Besides, the highest rate of graduation becomes a determining factor of the local prestige and its leaders. Thus the teachers become the main target to meet the local leaders' desire. It makes the teachers orient themselves more toward knowledge as the preparation for the examination compared to the development of the students' competence, and this ends up with the cognitive evaluation only. The presence of the evaluation that is oriented toward scores makes the students learn only to get scores rather than their quality. Manipulating learning achievement to meet the requirements of the stakeholders is also often done. Finally, this stunts teacher professional development. Some institutional policies restrict teachers from freely deciding about their autonomy as teachers, such as determining student graduation (Sardabi et al., 2018). The stakeholders' policies to put more importance in the examination is a barrier to the teacher selfdevelopment (Hairon \& Dimmock, 2012). The leaders' preference for high test scores makes the teachers want to pursue the test scores (Louis, 2012). Leaders should give teachers the autonomy to do their jobs by their context (Keesing-styles et al., 2013; Krantz \& Fritzén, 2017). In other words, leaders play a significant role in making an effective evaluation practice successful (Hill, 2011).

Examples of teachers' statements that are related to discrepancies that occur are as follows.

"I think there is a slight discrepancy, the teaching is theme-based, while the evaluation contentbased. The students sometimes get confused identifying material contents."

"The teaching process stresses the importance of developing five characters, and the teacher has to consider students one by one in teaching and evaluation. If there are many students in a learning group, the teacher has difficulty in giving the evaluation, especially in a lower grade whose students are hyperactive."

"Curriculum requirements and the implementation are not in line, plus there is stakeholder intervention."

\section{Weak Teacher-Parent Partnership}

The relation between teachers and parents has a powerful effect on the opportunity of teachers in developing their professional and the students' success in learning. A weak teacher-parent partnership makes all the responsibility for the students' success be burdened to the teacher so that this limits the teacher in developing himself or herself. Some parents are less aware of their duty to educate their children in a way that is in line with the process at school. Parent's busyness is one of the causes. Parents with middle to low economic abilities often do not have the time to educate their children at home. As a result, the children are often left behind in learning in the classroom and cannot get much attention from the teacher. The teacher also finds difficulty in communicating directly with the parents. Although some schools have online parents' organization, there often occur miscommunications on the part of the parents in understanding the messages sent by the teachers. Finally, the parents blamed the teachers for their children's failure. It shows that the parents do not trust teachers, and this harms the teachers themselves (Skaalvik \& Skaalvik, 2011). On the other hand, teachers need information from parents to develop an appropriate strategy to teach their students (Larocque et al., 2011), which is, of course, related to teacher professional development. The problem with the partnership occurs because of some factors such as the difficulty of transmitting information to parents, lack of parents' time, parents' economic problems, parents' lack of education, and inefficient communication (Hobjil, 2014; Williams \& Sánchez, 2011). In 
other words, teacher and parent commitment that go parallel will have a potential effect on the students so that parents have to become an equal partner of the teachers in child education (Westergård, 2013). The parents with high involvement in their children's education help the children to reach a better learning achievement compared with those with a low involvement (Öztürk, 2013; Powell et al., 2010).

"Not yet well developed. There is a lack of parents' support in optimizing their children's potentiality. Parents do not educate their children at home in order to be able to attend lessons at school."

"There is a lack of parents' active participation in the partnership to enhance educational quality. Parents just leave too much for the teachers/ school. "

\section{CONCLUSIONS}

Based on the aims and the discussion of the findings of this study, teacher professional, and its development face some barriers. The first barrier is the teacher's too much workload. For example, 24 teaching hours, doing the teaching administration in a rigid form and consist of many pages, and various additional tasks outside of teaching, which cause teachers to have a limited time to develop their professional. The second barrier is the lack of commitment on the part of the teachers to teach wholeheartedly. It is also a significant barrier to their professional. This phenomenon occurs not only among the teachers who are government workers but also among non-government worker teachers and old teachers. Lack of support from colleagues to the teacher's effort at developing his or her professional also becomes a barrier. Teachers with good dedication often end their effort because of the lack of support from their colleagues. This degradation occurs because of the paradoxical school system. The third barrier is support, monitoring, and supervision from the principal and supervisor that is not sufficient in various schools, which makes teachers less enthusiastic about developing themselves sustainably. The fourth barrier is the opportunity, and the custom of doing self-development is still limited and becomes a severe barrier to teacher professional. The lack of time available causes it due to too much workload. The fifth barrier is the low contribution of professional development activities through KKG to teacher professional. KKG is only a formality, and the process is unsustainable. The sixth barrier is the discrepancy within the requirements of the curriculum and the application in the field. It is worsened by the requirements of the stakeholders to improve the local prestige. The last barrier is the weak teacher-parent partnership, which makes all the responsible be burdened to the teachers, which limits the teachers' opportunity to develop themselves. Based on these findings, there is a need to develop partnerships with various stakeholders to overcome the existing barriers gradually and sustainably. The loss of various barriers to their competence development gives the teachers more opportunities to develop themselves sustainably. It cannot be denied that this study also has limitations. The limitation in question is that findings must be generalized carefully for contexts, regions, and participants with different backgrounds.

\section{REFERENCES}

Ada, E., \& Kartal, E. E. (2020). Professional Anxieties of Preschool Teacher Candidates. İlköğretim Online, 19(4), 2017-2031. https://doi.org/10.17051/ilkonline.2020.763209

Allen, N., Grigsby, B., \& Peters, M. L. (2015). Does leadership matter ? Examining the Relationship Among Transformational Leadership , School Climate, and Student Achievement. International Journal of Educational Leadership Preparation, 10(2), 1-22. https://files.eric.ed.gov/fulltext/EJ1083099.pdf

Altınay-Gazi, Z. (2017). Technology as Mediation Tool for Improving Teaching Profession in Higher Education Practices. EURASIA Journal of Mathematics, Science and Technology Education, 13(3), 803813. https://doi.org/10.12973/eurasia.2017.00644a

An, Y.-J., \& Reigeluth, C. (2011). Creating Technology-Enhanced, Learner-Centered Classrooms: K-12 Teachers' Beliefs, Perceptions, Barriers, and Support Needs. Journal of Digital Learning in Teacher Education, 28(2), 54-62. https://files.eric.ed.gov/fulltext/EJ960151.pdf

Anyolo, E. O., Kärkkäinen, S., \& Keinonen, T. (2018). Implementing Education for Sustainable Development in Namibia : School Teachersí Perceptions and Teaching Practices. Journal of Teacher Education for Sustainability, 20(1), 64-81. https://doi.org/10.2478/jtes-2018-0004

Bayar, A. (2014). The Components of Effective Professional Development Activities in terms of Teachers' Perspective. International Online Journal of Educational Sciences, 6(2), 319-327. https://doi.org/10.15345/iojes.2014.02.006

Berestova, A., Gayfullina, N., \& Tikhomirov, S. (2020). Leadership and Functional Competence Development in Teachers : World Experience. International Journal of Instruction, 13(1), 607-622. https://doi.org/. https://doi.org/10.29333/iji.2020.13139a

Bicer, A., \& Capraro, R. M. (2017). Longitudinal Effects of Technology Integration and Teacher Professional 
Development on Students ' Mathematics Achievement. 8223(3), 815-833. https://doi.org/10.12973/eurasia.2017.00645a

Blatchford, P., Bassett, P., \& Brown, P. (2011). Examining the effect of class size on classroom engagement and teacher e pupil interaction: Differences in relation to pupil prior attainment and primary vs . secondary schools. Learning and Instruction, 21(6), 715-730. https://doi.org/10.1016/j.learninstruc.2011.04.001

Bogler, R., \& Somech, A. (2004). Influence of teacher empowerment on teachers ' organizational commitment, professional commitment and organizational citizenship behavior in schools. Teaching and Teacher Education, 20(3), 277-289. https://doi.org/10.1016/j.tate.2004.02.003

Brennan, L. M. O., Bradshaw, C. P., \& Furlong, M. J. (2014). Influence of Classroom and School Climate on Teacher Perceptions of Student Problem Behavior. School Ment Health, 6(2), 125-136. https://doi.org/10.1007/s12310-014-9118-8

Brühwiler, C., \& Blatchford, P. (2011). Effects of class size and adaptive teaching competency on classroom processes and academic outcome. Learning and Instruction, 21(1), 95-108. https://doi.org/10.1016/j.learninstruc.2009.11.004

Buchs, C., Filippou, D., Pulfrey, C., \& Volpé, Y. (2017). Challenges for cooperative learning implementation : reports from elementary school teachers. Journal of Education for Teaching, 43(3), 296-306. https://doi.org/10.1080/02607476.2017.1321673

Burgess, J., Robertson, G., \& Patterson, C. (2010). Curriculum implementation : Decisions of early childhood teachers. Australasian Journal of Early Childhood, 35(3), 51-59. https://doi.org/10.1177/183693911003500307

Celik, S. (2012). Competency Levels of Teachers in Using Interactive Whiteboards. Contemporary Educational Technology, 3(2), 115-129. https://doi.org/10.30935/cedtech/6072

Cooper, T. (2017). Curriculum Renewal : Barriers to Successful Curriculum Change and Suggestions for Improvement. Journal of Education and Training Studies, 5(11), 115-128. https://doi.org/10.11114/jets.v5i11.2737

Delors, J., Al Mufti, I., Amagi, I., Carneiro, R., Chung, F., Geremek, B., Gorham, W., Kornhauser, A., Manley, M., Padrón Quero, M., Savane, M. A., Singh, Karan Stavenhagen, R., Suhr, M. W., \& Nanzhao, Z. (1996). Learning: the treasure within; report to UNESCO of the International Commission on Education for the Twenty-first Century (highlights). UNESCO. https://unesdoc.unesco.org/ark:/48223/pf0000102734

Delvaux, E., Vanhoof, J., Tuytens, M., Vekeman, E., Devos, G., \& Petegem, P. Van. (2013). How may teacher evaluation have an impact on professional development? A multilevel analysis. Teaching and Teacher Education, 36, 1-11. https://doi.org/10.1016/j.tate.2013.06.011

Dixon, F. A., Yssel, N., McConnell, J. M., \& Hardin, T. (2014). Differentiated instruction, professional development, and teacher efficacy. Journal for the Education of the Gifted, 37(2), 111-127. https://doi.org/10.1177/0162353214529042

Eyal, O., \& Roth, G. (2011). Principals ' leadership and teachers ' motivation Self-determination theory analysis. Journal of Educational Administration, 49(3), 256-275. https://doi.org/10.1108/09578231111129055

Fan, F. A. (2012). Class Size: Effects on Students' Academic Achievements and Some Remedial Measures. Research In Education, 87(1f), 95-98. https://doi.org/10.7227/RIE.87.1.7

Fishman, B., Konstantopoulos, S., Kubitskey, B. W., Vath, R., Park, G., Johnson, H., \& Edelson, D. C. (2013). Comparing the Impact of Online and Face-to-Face Professional Development in the Context of Curriculum Implementation. Journal of Teacher Education, 64(5), 426-438. https://doi.org/10.1177/0022487113494413

Gemeda, F. T., \& Tynjälä, P. (2015). Professional Learning of Teachers in Ethiopia: Challenges and Implications for Reform Professional Learning of Teachers in Ethiopia : Challenges and Implications. Australian Journal of Teacher Education, 40(5), 1-26. http://dx.doi.org/10.14221/ajte.2015v40n5.1

Ghorbani, S., Ebrahim, S., \& Jafari, M. (2018). Learning to Be : Teachersí Competences and Practical Solutions : A Step Towards Sustainable Development. 20(1). https://doi.org/10.2478/jtes-2018-0002

Gotch, C. M., \& French, B. F. (2013). Elementary Teachers ' Knowledge and Self-Efficacy for Measurement Concepts. The Teacher Educator, 48(1), 46-57. https://doi.org/10.1080/08878730.2012.740150

Griffin, P., McGaw, B., \& Care, E. (2012). Assessment and teaching of 21st century skills. In Assessment and teaching of 21st century skills (Vol. 9789400723). https://doi.org/10.1007/978-94-007-2324-5

Hairon, S., \& Dimmock, C. (2012). Singapore schools and professional learning communities: Teacher professional development and school leadership in an Asian hierarchical system. Educational Review, 64(4), 405-424. https://doi.org/10.1080/00131911.2011.625111

Hill, M. F. (2011). ' Getting traction ': enablers and barriers to implementing Assessment for Learning in secondary schools. Assessment in Education: Principles , Policy \& Practice, 18(4), 347-364. 
https://doi.org/10.1080/0969594X.2011.600247

Hobjil, A. (2014). Challenges in continuing education of primary and preschool teachers in Romania: teachers - students ' parents communication. Procedia - Social and Behavioral Sciences, 142, 684-690. https://doi.org/10.1016/j.sbspro.2014.07.598

Høigaard, R., Giske, R., \& Sundsli, K. (2012). Newly qualified teachers ' work engagement and teacher efficacy influences on job satisfaction, burnout, and the intention to quit. European Journal of Teacher Education, 35(3), 347-357. https://doi.org/10.1080/02619768.2011.633993

Hoque, K. E., Alam, G. M., \& Abdullah, A. G. K. (2011). Impact of teachers ' professional development on school improvement - an analysis at Bangladesh standpoint. Asia Pacific Education Review, 12, 337348. https://doi.org/10.1007/s12564-010-9107-z

Huber, S. G., \& Muijs, D. (2010). School Leadership Effectiveness : The Growing Insight in the Importance of School Leadership for the Quality and Development of Schools and Their Pupils. In School Leadership - International Perspectives. Studies in Educational Leadership, vol 10. (pp. 57-77). https://doi.org/10.1007/978-90-481-3501-1

I'Anson, J., \& Eady, S. (2017). Partnership as Educational Policy Imperative : An Unquestioned. Professions and Professionalism, 7(3), 1-17. https://doi.org/http://doi.org/10.7577/pp.1814

Ilomäki, L., Paavola, S., Lakkala, M., \& Kantosalo, A. (2014). Digital competence - an emergent boundary concept for policy and educational research. Education and Information Technologies, 21(3), 655-679. https://doi.org/10.1007/s10639-014-9346-4

Keesing-styles, L., Nash, S., \& Ayres, R. (2013). Managing curriculum change and 'ontological uncertainty' in tertiary education. Higher Education Research \& Development, 1-14. https://doi.org/10.1080/07294360.2013.841655

KEMDIKBUD, P. I._. (2020). Sambutan. PPPPTK IPA Kemdikbud.

KILINÇ, A. Ç. (2014). Examining the Relationship between Teacher Leadership and School Climate. Educational Sciences: Theory \& Practice, 14(5), 1729-1742. https://doi.org/10.12738/estp.2014.5.2159

Kim, H. J., Miller, H. R., Herbert, B., Pedersen, S., \& Loving, C. (2012). Using a Wiki in a Scientist-Teacher Professional Learning Community: Impact on Teacher Perception Changes. Journal of Science Education and Technology, 21(4), 440-452. https://doi.org/10.1007/s10956-011-9336-x

Kinman, G., Wray, S., \& Strange, C. (2011). Emotional labour , burnout and job satisfaction in UK teachers : The role of workplace social support. Educational PsychologyA, 31(7), 843-856. https://doi.org/10.1080/01443410.2011.608650

Kolbe, K. D. (2015). Knowledge, Attitudes and Behaviour regarding Waste Management in a Grammar and a Comprehensive School in England - Results from a School Questionnaire. Journal of Teacher Education for Sustainability, 17(1), 58-71. https://doi.org/10.1515/jtes-2015-0005

Krantz, J., \& Fritzén, L. (2017). From Expert to Novice? The Influence of Management by Documents on Teachers ' Knowledge Base and Norms. Professions and Professionalism, 7(3), 1-16. http://doi.org/10.7577/pp.2113

Kunter, M., Klusmann, U., Baumert, J., Richter, D., Voss, T., \& Hachfeld, A. (2013). Professional competence of teachers: Effects on instructional quality and student development. Journal of Educational Psychology, 105(3), 805-820. https://doi.org/10.1037/a0032583

Larocque, M., Kleiman, I. R. A., \& Darling, S. M. (2011). Parental Involvement: The Missing Link in School Achievement. Preventing School Failure, 55(3), 115-122. https://doi.org/10.1080/10459880903472876

Lee, J. C., Zhang, Z., \& Yin, H. (2011). A multilevel analysis of the impact of a professional learning community , faculty trust in colleagues and collective efficacy on teacher commitment to students. Teaching and Teacher Education, 27(5), 820-830. https://doi.org/10.1016/j.tate.2011.01.006

Liu, S. (2013). Exploring the Instructional Strategies of Elementary School Teachers When Developing Technological , Pedagogical , and Content Knowledge via a Collaborative Professional Development Program. International Education Studies, 6(11), 58-68. https://doi.org/10.5539/ies.v6n11p58

Louis, K. S. (2012). External mandates and instructional leadership : school leaders as mediating agents. $\begin{array}{llll}\text { Journal of Educational } & \text { 6dministration, 50(5), }\end{array}$ https://doi.org/10.1108/09578231211249853

Martín-gutiérrez, J., Fabiani, P., Benesova, W., Dolores, M., \& Mora, C. E. (2015). Computers in Human Behavior Augmented reality to promote collaborative and autonomous learning in higher education. Computers in Human Behavior, 51, 752-761. https://doi.org/10.1016/j.chb.2014.11.093

Morse, J. M., \& Field, P. A. (1995). Nursing Research: The Application of Qualitative Approaches (2nd ed.). Chapman \& Hall.

Mulryan-kyne, C. (2010). Teaching in Higher Education Teaching large classes at college and university 
level: challenges and opportunities. Teaching in Higher Education, 15(2), 175-185. https://doi.org/10.1080/13562511003620001

Nassaji, H. (2015). Qualitative and descriptive research: Data type versus data analysis. Language Teaching Research, 19(2), 129-132. https://doi.org/10.1177/1362168815572747

Otero, M. R., \& Llanos, V. C. (2019). Difficulties Faced by the In-service Mathematics Teachers Planning Lessons based on Questioning during a Training Course. International Journal of Research in Education and Science (IJRES), 5(2), 429-436. https://files.eric.ed.gov/fulltext/EJ1203819.pdf

Öztürk, M. (2013). Barriers to Parental Involvement for Diverse Families in Early Childhood Education. Journal of Educational and Social Research, 3(7), 13-16. https://doi.org/10.5901/jesr.2013.v3n7p13

Parker, M., Patton, K., Tannehill, D., Parker, M., Patton, K., \& Tannehill, D. (2012). Mapping the landscape of communities of practice as professional development in Irish physical education. Irish Educational Studies, 31(3), 331-327. https://doi.org/10.1080/03323315.2012.710067

Powell, D. R., Son, S., File, N., \& San Juan, R. R. (2010). Parent - school relationships and children 's academic and social outcomes in public school pre-kindergarten. Journal of School Psychology, 48(4), 269-292. https://doi.org/10.1016/j.jsp.2010.03.002

Rahayu, S. B. (2011). Studi Evaluatif Tentang Kegiatan Kelompok Kerja Guru Matematika Dalam Pelaksanaan Kurikulum Tingkat Satuan Pendidikan Pada Sekolah Dasar di Kecamatan Jembrana. Jurnal Pendidikan Dasar, 1(1). http://pasca.undiksha.ac.id/ejournal/index.php/jurnal_pendas/article/view/42/41

Riastini, P. N., Wati, C. S., Prodjosantoso, A. K., \& Suryadarma, I. (2019). Is There any Difference in Waste Consciousness between National Eco- Schools and Others? International Journal of Instruction, 12(4), 513-528. https://doi.org/10.29333/iji.2019.12433a

Riastini, P. N., Widowati, A., Ratnasari, Y., \& Suryadarma, I. (2019). Enganging Balinese Culture and Technology in Digital Era : A Review t o Foster Primary Teachers ' Competencies. 6th International Conference on Educational Research and Innovation (ICERI 2018), 330(Advances in Social Science, Education and Humanities Research), 244-248. https://doi.org/10.2991/iceri-18.2019.50

Saavedra, A. R., \& Opfer, V. D. (2012). Learning 21st-century skills requires 21st-century teaching. Phi Delta Kappan, 94(2), 8-13. https://doi.org/10.1177/003172171209400203

Sardabi, N., Biria, R., \& Golestan, A. A. (2018). Reshaping Teacher Professional Identity through Critical Pedagogy- Informed Teacher Education. International Journal of Instruction, 11(3), 617-634. https://doi.org/10.12973/iji.2018.11342a

Schleicher, A. (ed). (2012). Preparing Teachers and Developing School Leaders for the 21st Century: Lessons from around the World. OECD Publishing. http://dx.doi.org/10.1787/9789264174559-en

Shukla, S. (2014). Teaching Competency , Professional Commitment and Job Satisfaction-A Study of Primary School Teachers. IOSR Journal of Research \& Method in Education, 4(3 (II)), 44-64. https://doi.org/10.9790/7388-04324464

Skaalvik, E. M., \& Skaalvik, S. (2011). Teacher job satisfaction and motivation to leave the teaching profession : Relations with school context, feeling of belonging, and emotional exhaustion. Teaching and Teacher Education, 27(6), 1029-1038. https://doi.org/10.1016/j.tate.2011.04.001

Smith, J., \& Hu, R. (2013). Rethinking Teacher Education: Synchronizing Eastern and Western Views of Teaching and Learning to Promote 21 st Century Skills and Global Perspectives. Education Research and Perspectives, 40, 86-108. https://eric.ed.gov/?id=EJ1007188

Sumaryanta, Mardapi, D., Sugiman, \& Herawan, T. (2018). Assessing Teacher Competence and Its Followup to Support Professional Development Sustainability. Journal of Teacher Education for Sustainability, 20(1), 106-123. https://doi.org/10.2478/jtes-2018-0007

Tajasom, A., \& Ahmad, Z. A. (2011). Principals ' leadership style and school climate : teachers ' perspectives from Malaysia. The International Journal OfLeadership in Public Services, 7(4), 314-333. https://doi.org/10.1108/17479881111194198

Tanang, H., Djajadi, M., Abu, B., \& Mokhtar, M. (2014). Challenges of Teaching Professionalism Development : A Case Study in Makassar , Indonesia. Journal of Education and Learning, 8(2), 132143. http://dx.doi.org/10.11591/edulearn.v8i2.215

Thomson, M. M., \& Gregory, B. (2013). Elementary Teachers' Classroom Practices and Beliefs in Relation to US Science Education Reform: Reflections from within. International Journal of Science Education, 35(11), 1800-1823. https://doi.org/10.1080/09500693.2013.791956

Tuba, G., Güneş, G., \& Ebru, G. (2013). Evaluation of Primary School Teachers ' Technological Self-Efficacy. International Online Journal of Educational Sciences, 5(1), 42-51. http://www.iojes.net/?mod=makale_tr_ozet\&makale_id=41148

Vangrieken, K., Meredith, C., Packer, T., \& Kyndt, E. (2017). Teacher communities as a context for professional development: A systematic review. Teaching and Teacher Education, 61, 47-59. 
https://doi.org/10.1016/j.tate.2016.10.001

Vermunt, J. D., \& Endedijk, M. D. (2011). Patterns in teacher learning in different phases of the professional career. Learning and Individual Differences, 21(3), 294-302. https://doi.org/10.1016/j.lindif.2010.11.019

Westergård, E. (2013). Teacher Competencies and Parental Cooperation. International Journal about $\begin{array}{llll}\text { Parents in } & \text { Education, }\end{array}$ http://www.ernape.net/ejournal/index.php/IJPE/article/viewFile/270/194

Whitworth, B. A., \& Chiu, J. L. (2015). Professional Development and Teacher Change: The Missing Leadership Link. Journal of Science Teacher Education, 26(2), 121-137. https://doi.org/10.1007/s10972-014-9411-2

Williams, T. T., \& Sánchez, B. (2011). Identifying and Decreasing Barriers to Parent Involvement for InnerCity Parents. Youth \& Society, 45(1), 54-74. https://doi.org/10.1177/0044118X11409066

Winingsih, L. H. (2013). Peran Pemerintah Daerah, LPMP dan P4TK Dalam Meningkatkan Profesionalisme Guru. Jurnal Pendidikan Dan Kebudayaan, 19(4), 579-593. https://doi.org/10.24832/jpnk.v19i4.311

Yüksel, H. G. (2014). Teachers of the future : Perceived teaching competences and visions of pre-service English language teachers. International Journal of Human Sciences, 11(2), 27-39. https://doi.org/10.14687/ijhs.v11i2.2920

Zakharov, W., Strobel, J., \& Diefes-dux, H. A. (2020). Teacher Level Factors and Student Achievement in a Engineering Education Professional Development Program. International Journal of Research in Education and Science (IJRES), 6(1), 48-60. https://doi.org/10.46328/ijres.v6i1.527

Zedko, M., \& Sumual, I. (2017). Evaluation of Primary School Teachers ' Pedagogical Competence in Implementing Curriculum. Journal of Education and Learning, 11(3), 343-350. http://journal.uad.ac.id/index.php/EduLearn/article/view/6429 